\title{
Anzac Parade and our changing narrative of memory'
}

\author{
IAN A. DEHLSEN
}

\section{Abstract}

Australian historian Ken Inglis once called Canberra's Anzac Parade 'Australia's Sacred Way'. A quasi-religious encapsulation of the military legends said to define our national character. Yet, it remains to be discussed how the memorials on Anzac Parade have been shaped by these powerful and pervasive narratives. Each memorial tells a complex story, not just about the conflicts themselves but also the moral qualities the design is meant to invoke. The Anzac Parade memorials chart the changing perceptions of Australia's military experience through the permanence of bronze and stone. This article investigates how the evolving face of Anzac Parade reflects Australia's shifting relationship with its military past, with a particular emphasis on how shifting social, political and aesthetic trends have influenced the memorials' design and symbolism. It is evident that the guiding narratives of Anzac Parade have slowly changed over time. The once all-pervasive Anzac legends of Gallipoli have been complemented by multicultural, gender and other thematic narratives more attuned to contemporary values and perceptions of military service.

[This memorial] fixes a fleeting incident in time into the permanence of bronze and stone. But this moment in our history-fifty years ago-is typical of many others recorded not in monuments, but in the memories of our fighting men told and retold ... until they have passed into the folklore of our people and into the tradition of our countries. ${ }^{2}$

These were the words of New Zealand Deputy Prime Minister J.R. Marshall at the unveiling of the Desert Mounted Corps Memorial on Anzac Parade, Canberra, in the winter of 1968. His speech eloquently captures the nature of war memorials as the locus of veneration for a nation's military narratives, traditions and values. The memorials hunkered in the margins of Anzac Parade each tell a story of how Australia

1 This article was written prior to the construction of the National Boer War Memorial, which was unveiled on 17 May 2017, and the Australian Peacekeeping Memorial, which will be opened on 14 September 2017.

2 J.R. Marshal, speech given at the opening of the Desert Mounted Corps Memorial, Canberra, 19 April 1968. Quoted in Australian War Memorial, Desert Mounted Corps Memorial-Unveiling of replica in ANZAC Parade, Canberra, 19 Apr 1968 (Report to the board, 1968) Australian War Memorial: AWM27, 623/18. 
has perceived its complex military history and the fables we have wished to draw from it. Despite the 'permanence of bronze and stone', the grand narrative of Anzac Parade has changed in line with the nation it represents. The militaristic, masculine and nationalist Anzac mythos, which defined the Parade's early development, has slowly given way to new narratives. Multiculturalism, the changing role of women in Australian society and shifting perceptions of military service have each in turn shaped the design and interpretation of the memorials that now line Anzac Parade. Yet, the most important story is how the so-called Anzac legend itself has changed from all-pervasive myth to political object to complex but beloved legacy.

The main purpose of Anzac Parade, apart from its six-lane automotive function, is as a frame for the eight grand war memorials lining its fringes. Each set in its own little niche, they are detached from each other both spatially and thematically by glades of eucalypts.

Despite being some of the largest public art commissions in Australia's historynot to mention historians' love of debating the meaning of anything with Anzac in its title-little has been written academically about the importance of Anzac Parade. The definitive study of military memorialisation in Australia, Ken Inglis's Sacred Places: War Memorials in the Australian Landscape dedicates a scant few pages. Yet, within that space Inglis invokes a powerful honorific: Anzac Parade as 'The Sacred Way', a pilgrimage root for Australia's civic religion, in the style of classical antiquity. ${ }^{3}$

Anzac Parade has always held a special place in Canberra's history. With the decision to name Canberra as Australia's national capital in 1912, a competition was announced to design the new city. At the centre of the Walter and Marion Griffin's winning design was the so-called topographic 'land axis'; an imaginary line running between the summits of Mount Ainslie in the city's north-east and Red Hill in the south-west, bisected by the subsequently named Lake Burley Griffin. On the northern side, the Griffins had envisioned a tree-lined avenue along the land axis leading from the lakeshore to the foot of Mount Ainslie ${ }^{4}$ - a grand boulevard to break up the monotony of dense housing.

Crucially, Canberra's early development coincided with the great tragedy of the young Australian Commonwealth: the First World War. The conflict slowed construction considerably - a delay that profoundly changed the future of Anzac Parade.

3 Ken Inglis, Sacred Places: War Memorials in the Australian Landscape (Melbourne: Melbourne University Press, 2008), pp. 381-9.

4 National Capital Planning Authority, ANZAC Parade Design Studies (Report prepared by Lester Associates, 1991), National Capital Authority Library. 


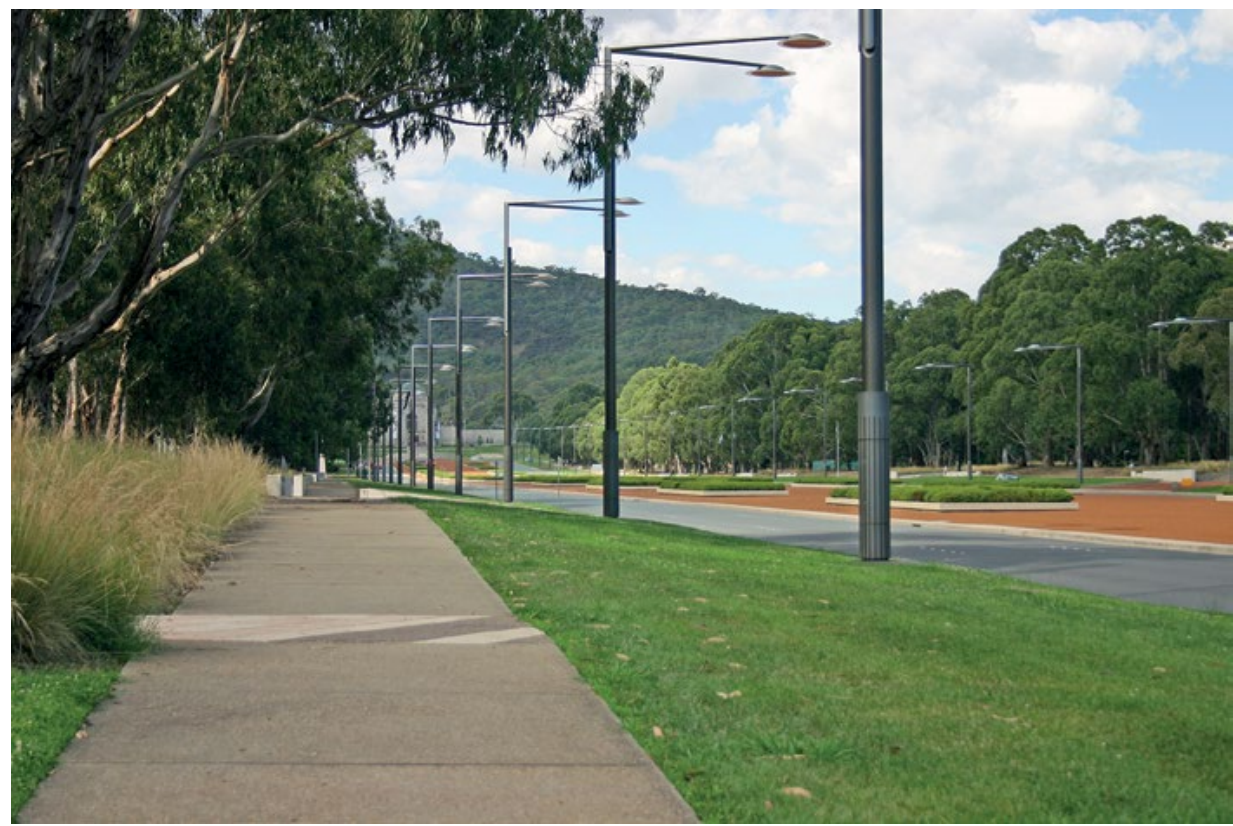

Figure 1: View north-east along Anzac Parade towards the Australian War Memorial.

Source: Author.

During the Gallipoli campaign, the news reports of British journalist Ellis Ashmead Bartlett made the Anzac soldiers appear extraordinarily valorous. His descriptions of the landings were vivid: a 'race of athletes ... who knew that they had been tried for the first time and not found wanting'. ${ }^{5}$ His was a vision of war that appealed to the emergent Australian identity, a battle waged between the nobility of the British race and the barbarity of the Prussian 'Hun'; a moral dichotomy rendered so expertly in the cartoons of Norman Lindsay and the speeches of wartime Prime Minister Billy Hughes.

During the post-war period, much consideration was directed toward what lessons could be learned from the conflict. This national reflection saw the emergence of the indelible 'Anzac legend', both as a redemptive and a moralising narrative and as a justification for the failures of Gallipoli and the sacrifices of the Western Front.

The Anzac legend was further reinforced by the first official Australian War Historian, Charles Bean; a man who had experienced Gallipoli first-hand and was committed to extolling the virtues he had observed in its combatants. ${ }^{6}$ In his voluminous

5 Ellis Ashmead-Barlett, quoted in 'ANZAC Legend' in Peter Dennis, Jeffrey Grey, Ewan Morris, Robin Prior, and Jean Bou (eds), The Oxford Companion to Australian Military History (Oxford: Oxford University Press, 2008), p. 38 .

6 Ken Inglis, C.E.W. Bean: Australian Historian (Brisbane: University of Queensland Press, 1969), pp. $26-7$. 
official history of the war, Bean propagated an image of the brash, resourceful and stoic digger as the pinnacle of Australian national identity: 'the big thing in the war for Australia was the discovery of the character of Australian men' ${ }^{7}$ Throughout his time on the Western Front and the Dardanelles, Bean had envisioned a war museum with which to edify future countrymen. The Australian War Memorial, the embodiment of Bean's vision, was part shrine, part museum. Situated at the far north-eastern end of the recently renamed Anzac Park, the War Memorial was a melange of architectural styles and symbolism dressed in sombre sandstone and bronze; a monolithic, stern, quasi-Byzantine proto-cathedral in the middle of a sheep paddock. Photographs taken around the time of the War Memorial's official opening in 1941 shows Bean's edifice almost pompously out of place. ${ }^{8}$

It was Emil Sodersten, one of the War Memorial's architects, who first suggested the northern land axis should be used as a ceremonial approach to the War Memorial. His 1936 urban plan for Anzac Park included water features and other public amenities to encourage the utilisation of the space. ${ }^{9}$ However, as the city expanded, it became increasingly apparent that Anzac Parade was a necessary traffic corridor. Under the auspices of town planner Sir William Holford, Anzac Parade was truncated at both ends by major roads, preventing its integration into the urban environment as both Griffin and Sodersten had envisioned. ${ }^{10}$

A federal government report from early 1961 noted that 'Canberra has singularly few monuments of any type', and that such monuments were required to inspire 'national sentiment'. Specifically, 'memorials relating to the exploits in times of war should be located along Anzac park where they will embellish the mall approaching the National War Memorial'. ${ }^{11}$ The renewed interest in the precinct was likely motivated by the approaching 50th anniversary of the Gallipoli campaign. ${ }^{12}$ The ornamentation of Anzac Parade also fit into Prime Minister Robert Menzies' desire to make Canberra into a modern city and a symbol of national pride.

\footnotetext{
7 Charles Bean, quoted in 'ANZAC Legend' in Peter Dennis, Jeffrey Grey, Ewan Morris, Robin Prior, and Jean Bou (eds), The Oxford Companion to Australian Military History (Oxford: Oxford University Press, 2008), p. 37.

8 Richard Strangeman produced a series of photographs of the construction of the Australian War Memorial, which are held by the memorial. Two were of particular interest in investigating the memorial's setting: a view from the partially completed dome (black-and-white photograph, dated 1/8/1940, Australian War Memorial: XS0112) and an aerial view of the completed memorial taken on the day of the opening (black-and-white photograph, dated 11/11/1941, Australian War Memorial: XS0190).

9 Emil Sodersten National War Memorial Canberra, Site Development and Approaches (Report to the War Memorial Board, 21/5/1936), quoted in National Capital Authority, ANZAC Parade Urban Design: Commissioned Competition (National Capital Authority Library: C21 NAT 'B' 17867, 1992), p. 35.

10 William Holford, quoted in National Capital Authority, ANZAC Parade Urban Design: Commissioned Competition (National Capital Authority Library: C21 NAT 'B' 17867, 1992), p. 38.

11 National Capital Development Commission, The Place of Monuments in the National Capital (Report to the National Memorials Committee, 1961, National Archives of Australia A463, 1964/875), p. 1.

12 Ibid., p. 3.
} 


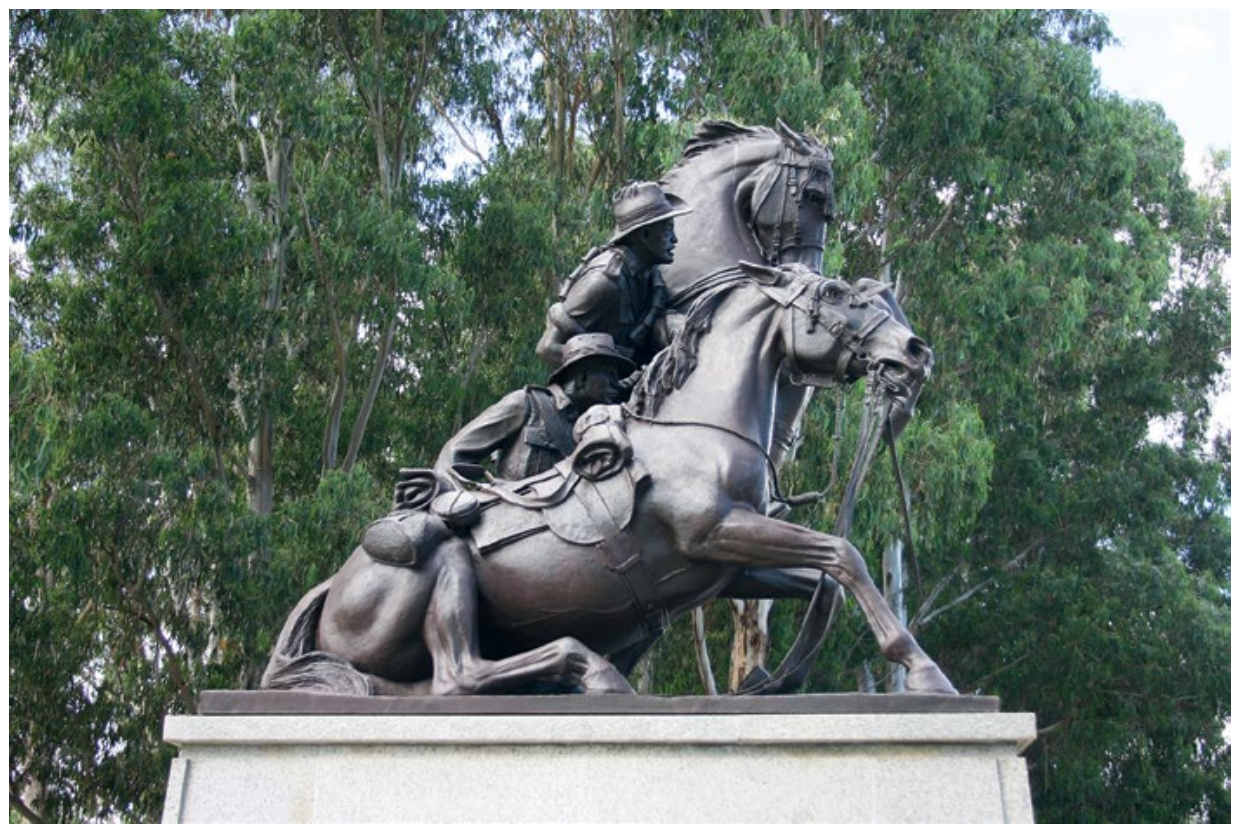

Figure 2: Desert Mounted Corps Memorial.

Source: Author.

The first memorial on Anzac Parade, the Desert Mounted Corps Memorial, was unveiled in 1968 (Figure 2). It was not an original design, but a copy of Bertram Mackennal and Web Gilbert's sculpture 'The ANZACs', originally erected in 1932 at Port Said, Egypt, overlooking the entrance to the Suez Canal. The memorial commemorated the Australian and New Zealand soldiers killed during the Palestine, Sinai and Mesopotamian campaigns, ${ }^{13}$ and was partially funded by the troops themselves. ${ }^{14}$ The original memorial stood for 26 years before Egyptian rioters tore it down in a wave of anti-British sentiment during the Suez Crisis of 1956. ${ }^{15}$ The broken pieces were shipped back to Australia where sculptor Raymond Ewers was employed to recreate the sculpture. However, it was not Canberra but Albany, Western Australia, that was chosen as the site for the reconstituted memorial-Albany being the final port of departure for mounted troops headed for the Middle East.

The Albany decision, made by Minister for the Interior Gordon Freeth, proved exceedingly unpopular amongst surviving Light Horsemen as well as the public at large. Moreover, the fact that the new memorial was situated in Freeth's own electorate led to claims of 'petty parish-pub politics' ${ }^{16}$ Confidential documents from

13 The units specifically mentioned on the dedication plaque were the Australian Light Horse, the New Zealand Mounted Rifles, the Imperial Camel Corps and the Australian Flying Corps.

14 In a touching gesture, each soldier gave one day's pay toward the sculpture fund.

15 Ken Taylor, 'ANZAC Parade: A Landscape of Memory', in Canberra Historical Journal No. 36 (1996), p. 9.

16 Sydney Morning Herald, 'R.S.L. May Provide a Replica For Park', 31 December 1962. 
the period show that the decision was deeply influenced by the opinions of Sir George Holland, the powerful president of the Victorian Returned Servicemen's League (RSL), and a dogged anti-communist ally of his close friend Prime Minister Menzies. ${ }^{17}$ The reason for Holland's preference is unclear. Though it may have been out of spite toward the independent Light Horse associations' unanimous preference to situate the memorial in Canberra — an act that threatened the RSL's position as the sole voice of returned servicemen. After lobbying in person and in the press by the Light Horse associations, the federal government was effectively politically blackmailed into paying for a second version of the sculpture to be cast for Canberra. ${ }^{18}$

The deference shown by the conservative Menzies Government to the will of returned servicemen is evidence of the considerable power that the Anzac legend carried, even 50 years after the events of the First World War. In his 1994 book, ANZAC Memories: Living with the Legend, Alistair Thomson argued that a conservative and nationalistic version of the Australian military experience had evolved among returned diggers and the wider Australian community during the post-war years. It stemmed from an emotional need to believe in the patriotic narrative as a way of rationalising and celebrating what had been so destructive for so many. ${ }^{19}$ Historian Martin Crotty builds on Thomson's conclusion, arguing that returned servicemen, through organisations like the RSL, cultivated and perpetuated the exalted version of the Anzac story as a form of political leverage. In addition, Crotty contends that the proponents of the honorific model of Anzac desired to implement a militaristic doctrine of citizenship; whereby 'heeding the call' and offering one's life to defend the liberty and values of the nation entitled special privileges from the state they had served. ${ }^{20}$ This patriotic view of Anzac history came to dominate the memorials built on Anzac Parade until the late 1980s.

After the popular and political success of the Desert Mounted Corps Memorial, a movement was soon afoot to fill the next niche on Anzac Parade, this time with a monument to celebrate the 50th anniversary of the Royal Australian Air Force (RAAF) in 1973. Gilbert and Mackennal's Mounted Corps memorial was a wellexecuted but traditional design. Its symbolism was explicit and consistent with Billy Hughes' characterisation of the Light Horse as 'a story not less enthralling,

17 A.T. Griffith letter to E.J. Bunting, 11th March 1963, National Archives of Australia: A463, 1964/2781 PART 1, p. 4.

18 Doug Anthony letter to Robert Menzies, 5th May 1965, National Archives of Australia: A463, 1964/2781 PART 1. Menzies' backdown was somewhat softened by a convenient 11 th-hour change of heart by the RSL.

19 Alistair Thomson, ANZAC Memories: Living with the Legend (Melbourne: Oxford University Press, 1994), pp. 5-7.

20 Martin Crotty, 'The Anzac Citizen: Towards a History of the RSL', in Australian Journal of Politics and History Vol. 53, No. 2 (2007), p. 186. 
romantic and wonderful than the odyssey itself'. ${ }^{21}$ In this vein, the Australian War Memorial's director had initially recommended the commissioning of a safe figurative artist, Dennis Adams, for the Air Force Memorial. However, for reasons not readily apparent, Prime Minister Gorton decided to run an open competition for the design — a dangerous proposition whenever artists are involved.

The winning design was by Inge King, a young Jewish-German émigré and one of Australia's most acclaimed abstract sculptors. Her composition consisted of three subtly tapering stainless steel pylons; an abstract composition without figurative reference to the RAAF, except for the motto PER ARDUA AD ASTRA carved into the base (Figure 3). The design depicted ephemeral qualities of struggle against physical and spiritual obstacles through the metaphor of flight. The Queensland branch of the Air Force Association called it a 'monstrosity', 'devoid of Airforce interest'. ${ }^{22}$ Canberra airmen were so disaffected that they started building their own memorial in protest. ${ }^{23}$ Critics felt the public would not be able to decipher what the memorial was for let alone celebrate the qualities it symbolised. The intellectual, Modernist design also left airmen feeling isolated from the memorial, denied a sense of ownership. ${ }^{24}$

The controversy surrounding the Air Force Memorial meant that 10 years would pass before the political will returned to continue the Anzac Parade project. The Rats of Tobruk Memorial, opened in 1983, was a return to traditional concepts of memorialisation. The memorial is dominated by a sandstone obelisk decorated with a surging bronze flame; modelled after a similar obelisk erected by Australian troops at the Tobruk War Cemetery. ${ }^{25}$ Running around the base of the memorial is a small concrete trench styled after the famous line of fortifications where the seemingly unstoppable Germany army was held at bay during the Second World War. One of Australia's most inspiring victories, Tobruk was an obvious choice to restore faith in Anzac Parade. The simple and poignant obelisk projected the stoic virtue at the core of the Anzac legend.

21 Billy Hughes, speech given on the opening of the Desert Mounted Corps memorial, Port Said, Egypt, 1932. Quoted in Australian War Memorial, Desert Mounted Corps Memorial (Report to memorial board) AWM27, $623 / 18$.

22 Canberra News, 'Monstrosity Stays', 3 May 1971.

23 Dennis Blewett, 'Airman's Tribute to the Fallen Takes Shape', The Courier, 26 August 1971.

24 A sentiment played out rather more bluntly in the letters section of the Canberra Times. One former airman called it an 'insult to my service'. Another writer referred to King's sculpture as a load of outsized air-conditioning ducts. L.E. Radclyffe and A. Lindh respectively, letters to the editor, Canberra Times, 2 April 1973.

25 Canberra National Monuments Committee, A Proposal for a Memorial to the Rats of Tobruk (report to the committee, 1981) National Archives of Australia: A1209, 1982/690 PART 2. 


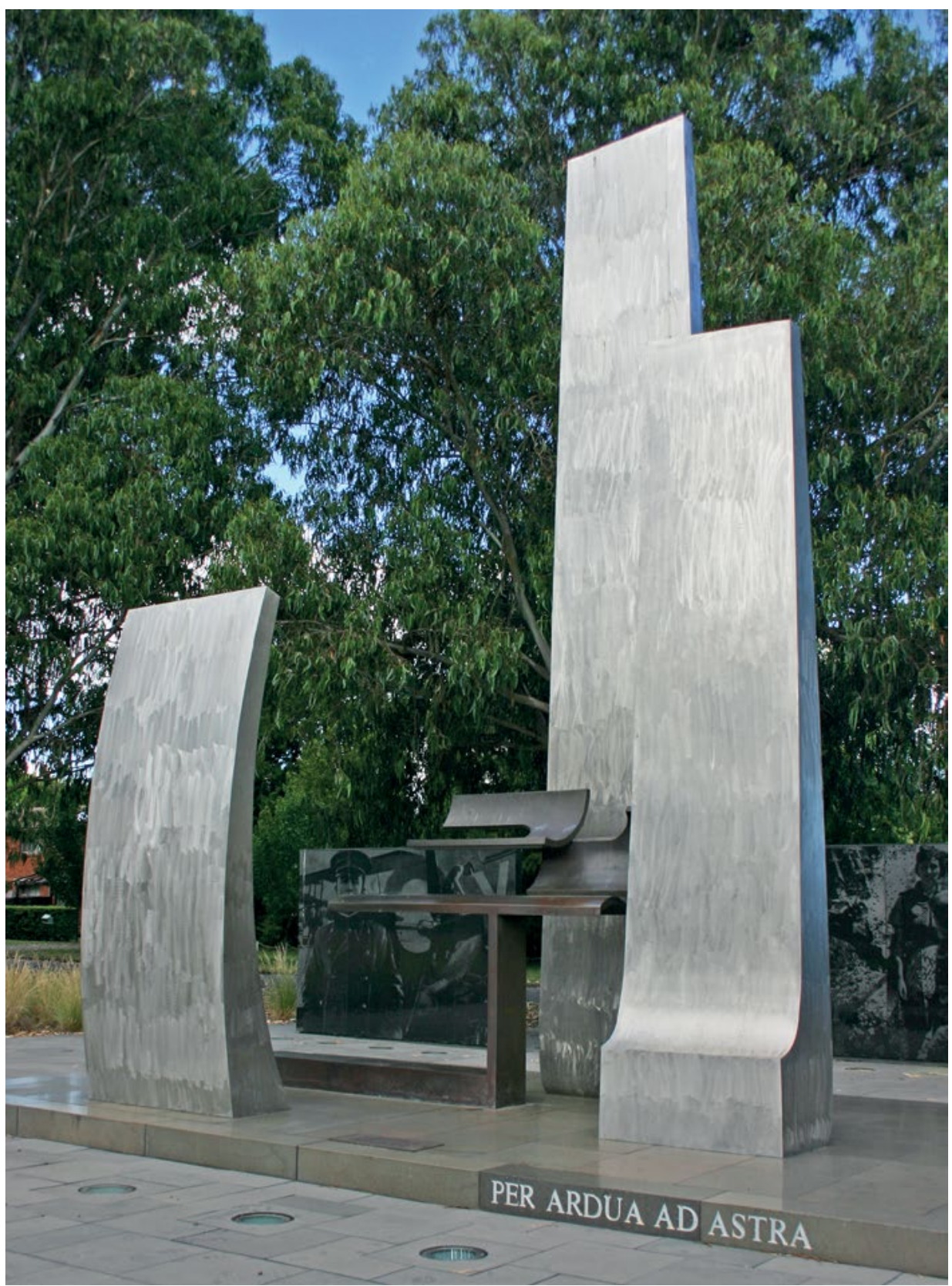

Figure 3: Royal Australian Air Force Memorial. Source: Author. 
The Tobruk Memorial was followed in 1986 by a memorial to celebrate the 75 th anniversary of the Royal Australian Navy. The design was again opened up to tender, but this time with the proviso that the memorial would be 'functional rather than symbolic ... [and] clearly recognisable and demonstrably a Naval Memorial without ambiguity'. ${ }^{26}$ The winning design by Canberra sculptor Ante Dabro recalls the work of the European Futurist sculptors of the early twentieth century. His vision was to tell a story about the interdependence of man and machine in modern combat. Entitled 'Ships and Sailors', the depicted figures and equipment in various marine poses emerge organically from a central bronze mass, reminiscent of an inverted whirlpool (Figure 4). ${ }^{27}$ The design is both dignified and dynamic, and is perhaps the most artistically interesting memorial along the Parade.

The Tobruk and Navy memorials were largely uncontroversial in their design and execution, the legends attached to these groups were undeniably positive, and the memorials themselves spoke directly to these perceptions. ${ }^{28}$ The same could be said of the memorial to the Australian Army unveiled in 1989, with its two fully kittedout bronze soldiers, rugged and wily in expression. The epitome of the Australian fighting man: 'fit for a recruiting poster or a department store window' ${ }^{29}$ Fit also to carry on the enduring Anzac legend, which had remained publicly unchallenged for 70 years by this time.

Academically, however, the old Anzac legend - as exemplified in the virile figures of the Army Memorial-had long been undergoing critical re-examination. In 1969, Ken Inglis delivered a lecture to the University of Queensland eulogising Charles Bean, who had passed away that year. His lecture presented a much more nuanced rationale for the 'cult of Anzac' in Bean's writing; attributing its heroism to Bean's romantic obsession with defining the Australian character in the context of a war that he personally found horrific and dehumanising. ${ }^{30}$ Inglis's lecture also told of how the experience of the First World War left Bean struggling to justify Australian involvement in the Second. ${ }^{31}$

During the 1980s and '90s, the work of Alistair Thomson attempted to reconsider alternative Anzac narratives, which had become supressed by the cultural hegemony of the patriotic version. The stories of the shell-shocked, the socialists and the disillusioned were unearthed and their struggles to fit within the larger Anzac narrative re-evaluated. ${ }^{32}$

26 National Capital Development Commission, National Memorial to the Australian Navy: Conditions for a Two Stage Design Competition (1963) National Archives of Australia: A1209, 1982/690 PART 3.

27 Sasha Grishin, 'Street Art Finds Favour', The Canberra Times, 9 May 1986.

28 Henry Reynolds and Marilyn Lake, 'Epilogue: Moving On?', in Marilyn Lake and Henry Reynolds (eds), What's Wrong with ANZAC? The Militarisation of Australian History (Sydney: University of New South Wales Press, 2011), p. 162.

29 Ken Inglis, Sacred Places, p. 383.

30 Inglis, C.E.W. Bean, p. 21.

31 Ibid., p. 29.

32 Thomson, ANZAC Memories, p. 8. 


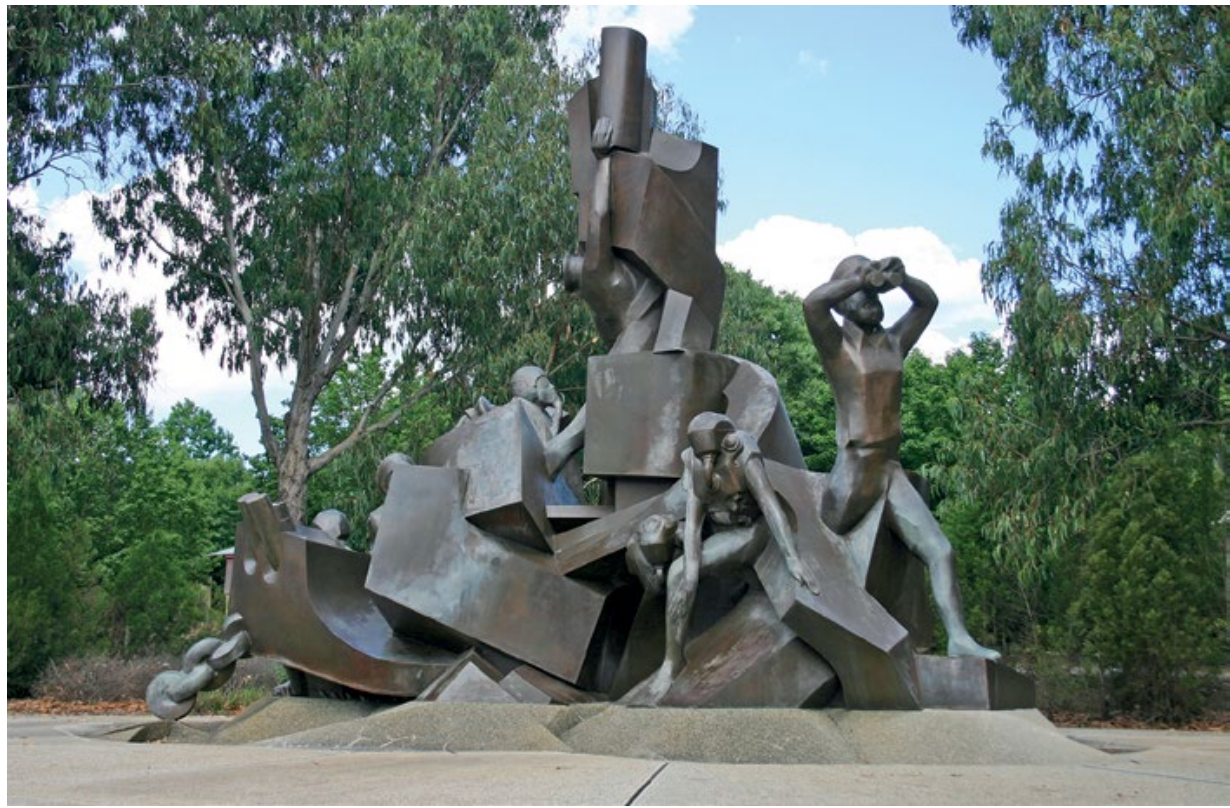

Figure 4: Royal Australian Navy Memorial.

Source: Author.

The tone of the Anzac Parade project changed markedly with the opening of the Kemal Ataturk Memorial in 1985. Often called the Gallipoli or Turkish Memorial, it was, in the words of Ken Inglis, 'one item in a round of sentimental diplomacy celebrating ... what was now perceived as the common ordeal of Gallipoli' ${ }^{33}$ The memorial is aesthetically underwhelming (a victim of design by committee), yet the symbolic narrative speaks clearly. Two former foes, set apart in culture and geography, brought together through their shared sacrifice and the magnanimity of Ataturk. The placement of the memorial in such a privileged position (being the closest niche to the Australian War Memorial) was a political quid pro quo, tied to the Turkish promise to officially rename Anzac Cove. Yet it did set a precedent: that multiple narratives could coexist on Anzac Parade.

The next new narrative to find its place on the 'Sacred Way' was the multicultural legacy of post-Second World War migration. The Australian Hellenic Memorial, opened in 1986, showed the growing acceptance of new immigrants in Australian society. Predominantly funded by the Greek-Australian community, the memorial was championed by both the RSL and Prime Minister Bob Hawke. In a speech launching the memorial appeal, Hawke paid tribute to the common experiences of Australians and Greeks in the Battle of Crete, as well as the 'shared commitment to the shared ideals of freedom and democracy'. Tellingly, he spoke of how the memorial

33 Inglis, Sacred Places, p. 384. 
'[reminds] us how successful have been our joint efforts to build a multicultural society which seeks to create equality of opportunity for all Australians. ${ }^{34}$ Hawke wanted to promote a new version of Australia, consistent with the increasingly internationalist values of the Australian Labor Party. ${ }^{35}$ Interestingly, as the relationship between Greece and Turkey was at a low ebb during the late 1980s, the construction of the Hellenic Memorial provoked a series of classified cables between Canberra and the Australian Embassy in Ankara as the Australian Government attempted to reassure the Turkish Government of the politically benign nature of the monument. ${ }^{36}$

The next two memorials erected along Anzac Parade were dedicated to what are often termed 'forgotten wars'. In the early 1980s, a single memorial was proposed to commemorate Australia's contribution to the anti-communist conflicts in SouthEast Asia, including the Korean and Vietnam Wars and Malayan Emergency. ${ }^{37}$ The idea was quickly abandoned, however, and was not revisited for more than a decade.

Division characterised Australia's collective experience of the Vietnam War. Many veterans felt, that in an effort to suppress the conflict from the national consciousness, their service was met with indifference or outright disdain. ${ }^{38}$ In the United States, where the feelings of rejection and isolation amongst Vietnam veterans were often even more pronounced, the push for national recognition had focused on the establishment of a national memorial commemorating the thousands of Americans killed during the war.

While war memorials are traditionally driven by either bureaucracy or patriotism, the Vietnam Veterans Memorial in Washington DC was an exception. It was ultimately the product of one man's obsession. Jean Scruggs, a psychology student and wounded veteran, allegedly conceived the memorial late one night after drunkenly watching the film Deer Hunter. ${ }^{39}$ He personally oversaw the fundraising for the project and was involved in selecting the memorial's controversial design. Scruggs had desired a memorial that commemorated the dead, rather than engaging with controversies of the war itself. The result was an enigmatic memorial; a chevron-shaped black stone wall with the names of the American casualties

\footnotetext{
34 Bob Hawke, Launching of the National Appeal for the Australian-Hellenic Memorial Canberra, 1 April 1987 [Press transcript], National Archives of Australia: A463, 1986/996.

35 Zoe Anderson, 'Reading "Multiculturalism": A Historiography of Policy and Ideal in Australia', in History Compass, Vol. 11, No. 11 (2013), p. 906.

36 Department of Foreign Affairs and Trade, Cable to the Australian Embassy in Turkey 29th May 1986, National Archives of Australia: A463, 1986/996, pp. 30-1.

37 Bob Ellicott letter to Malcom Fraser, 4th August 1980, National Archives of Australia: A1209, 1982/690 PART 1, p. 73.

38 Ambrose Crowe, The Battle After the War: The Story of Australia's Vietnam Veterans (Sydney: Allen \& Unwin, 1999), p. 10.

39 Jan Scruggs and Joel Swerdlow, To Heal a Nation: The Vietnam Veterans Memorial (New York: Harper Rowe, 1985), p. 7.
} 
carved chronologically in unadorned block letters, free of mentions of rank or unit. 'The Wall', as it was soon dubbed, was a landmark in war memorialisation. In the mind of its designer, Chinese-American architecture student Maya Lin, the purpose of the memorial was unapologetically apolitical and indifferent to the militarism of its subject: it was a memorial designed to connect the living to their memories of the dead and nothing more. There is no unitary narrative inherent in its design, no official meaning; there is only the personal stories the viewer projects onto the memorial. ${ }^{40}$ It largely skirts controversy by focusing on the universal certainties of war: death, grief, and memory. The memorial was criticised for its Formalist design and perceived lack of patriotism. Yet, once unveiled in 1982, the memorial proved hugely popular - the void-like design proved to be a huge asset, as visitors touched the names of the dead and brought along their own personal, esoteric tributes to their friends. More importantly, however, the Washington memorial was a symbol that the wider American population were willing to re-engage with veterans, even if they had personally opposed the war. The success of the American memorial gave inspiration to Australian veterans that a similar project could be effective on Anzac Parade.

Three factors sparked the campaign for a Vietnam War memorial on Anzac Parade. The first was the success of the Washington memorial. The second was the belated 'welcome home' march, held in Melbourne in 1987. Such marches were rituals held at the conclusion of Australia's more illustrious wars, and Vietnam veterans felt themselves denied. The third was the Evatt Royal Commission into Agent Orange exposure during the war. ${ }^{41}$ Despite not granting veterans the compensation they desired, the Commission contended that a memorial was key to reconnecting veterans with the wider community.

The Australian Vietnam Forces National Memorial, unveiled in 1992 by Prime Minister Paul Keating, was envisioned as a way of engaging with disaffected veterans looking for a sense of closure. ${ }^{42}$ Its design, in a postmodern, eclectic style, recalls a semi-enclosed chapel. It is constructed from three subtly curved concrete stelae capped with a suspended 'halo' of stone blocks. On one internal wall, an image of a helicopter dust-off is sand blasted into the stone casing - a scene encapsulating the war experience of many (Figure 5). On the opposite wall are a series of enigmatic quotations written in stainless steel letters. Some speak of the courage of soldiers and their place in the Australian military tradition, others speak of the isolation

40 Karal Ann Marling and Robert Silberman, 'The Statue near the Wall: The Vietnam Veterans Memorial and the Art of Remembering', Smithson Studies in American Art, Vol. 1, No. 1 (1987), p. 10.

41 For a discussion of Evatt's findings see Jeffery Grey, 'Vietnam, Anzac and the Veteran', in Peter Pierce, Jeff Doyle and Jeffrey Grey (eds), Vietnam Days: Australia and the Impact of Vietnam (Melbourne: Penguin Australia, 1991).

42 The use of the American veteran as opposed to the traditional returned serviceman in the title of the memorial has been seen by some as a snub directed toward the RSL and older servicemen who they believed had belittled the military experience. Ibid., pp. 178-80. 
and despondency on their return, while others conveyed the divisive impact of the war on society. The problems of reconciling the martial and anti-war narratives are overcome by addressing both simultaneously. For veterans, the memorial serves three purposes. First, it is commemorative, allowing a place to mourn the dead. Second, it attempts to rehabilitate the status of the Vietnam veteran in line with the other conflicts memorialised on Anzac Parade. Third, it is educative, not only in jingoistic military virtues, but in the reality of the conflict and its larger context in Australian history.

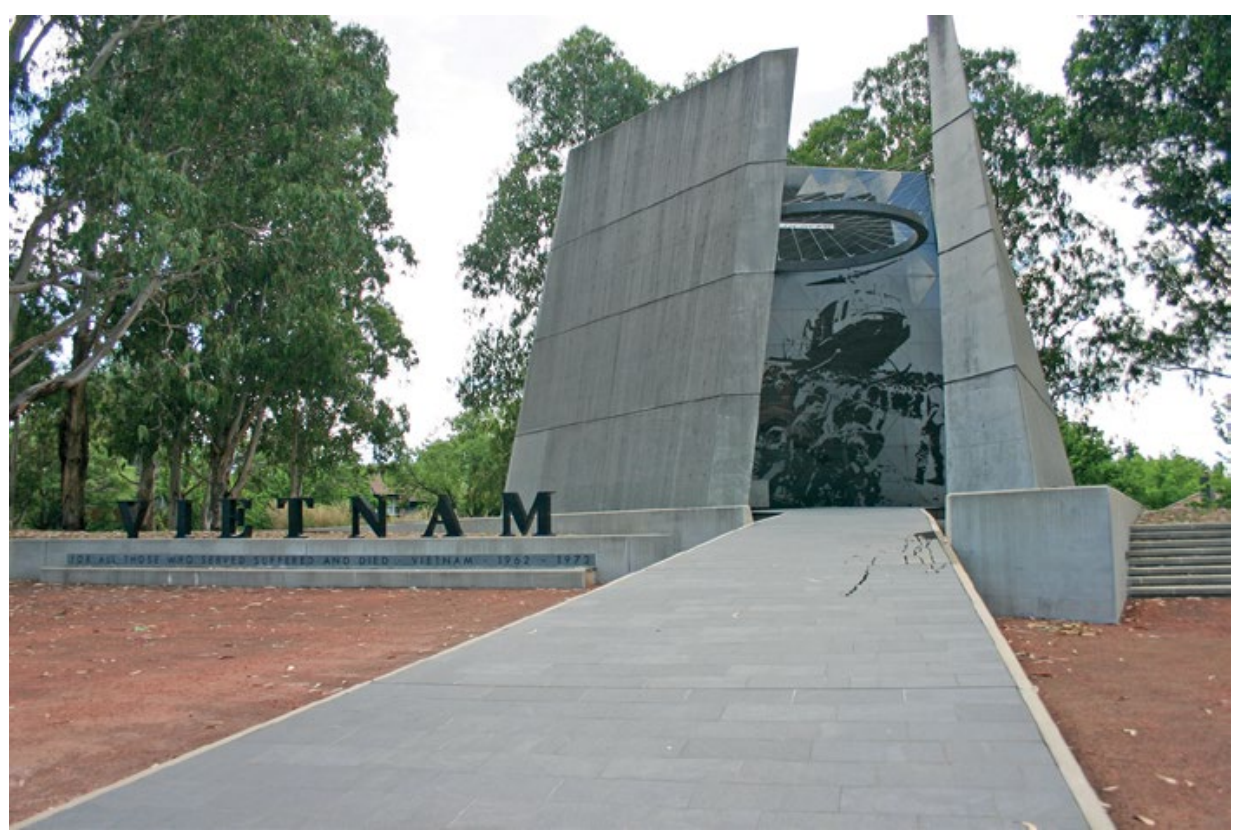

Figure 5: Australian Vietnam Forces National Memorial.

Source: Author.

The Korean War by comparison was a largely uncontroversial war that inspired an uncontroversial memorial. Australia's contribution was small and its body count low. It was a war fought at the height of anti-communist sentiment and was supported by those we were protecting. The Australian National Korean War Memorial, gifted in part by the South Korean Government, was opened in 1996, more than 40 years after the conflict had ended. Its design was somewhat Zen-like with its white pebbles, forest of steel poles and shrine-like marble building. ${ }^{43}$ Where the Vietnam Memorial was by necessity about reconciliation, the Korean Memorial encapsulated a narrative that could be celebrated, even if only in an understated manner.

43 Jeff Doyle, 'Another Forgotten War Remembered: The Australian National Korean War Memorial, ANZAC Parade, Canberra', in Peter Dennis and Jeffery Grey (ed.), The Korean War 1950-1953: A 50 Year Retrospective (Canberra: Army History Unit, 2000), p. 55. 
Australia's military narrative has undergone a considerable cultural and historiographical shift in recent times, with the Anzac legend coming under fire on multiple fronts. Numerous studies have challenged the factual accuracy of the mythological stories of First World War diggers, as well as those of later conflicts. Two polemical books edited by Australian Defence Force Academy academic Craig Stockings, Zombie Myths of Australian Military History (2010) and Anzac's Dirty Dozen (2012), argued that many of narratives that fuel Australia's collective military consciousness are built upon misconceptions or questionable historical understanding - the exceptionalism inherent in the Anzac legend being of particular concern. Historians argue that Australians were not 'born soldiers', physically and practically superior to their European compatriots. ${ }^{44}$ The second historiographical challenge to the Anzac legend has been more ideological. Henry Reynolds and Marilyn Lake's What's Wrong with Anzac? (2010) questions if the First World War creation myth is still relevant in modern Australia, and also if the militarism inherent in the Anzac legend is degrading other strains of the national discourse. ${ }^{45}$ These arguments further extend to how history is taught in schools and how (or if) we should celebrate our nation's military heritage. These new interpretations are often bitterly contested, especially in the context of the increasing reverence applied to First and Second World War soldiers in our national psyche and rituals. ${ }^{46}$

Even at the Anzac Day Dawn Service, the most solemn of Anzac rituals, there is a sense that the legend must evolve. In his keynote address on the 100th anniversary of the Gallipoli landing in 2015, Lieutenant-General David Morrison spoke of:

A line that connects us to those who lived 100 years ago ... a line made more whole by our recognition of the first people of this land and our sorrow for their treatment. It is a line given colour and vibrancy by our cultural richness and diversity, drawn as it is from migrants from all corners of our world. It is a line rooted in our freedom of expression and of belief, and the affirmation of our democratic nation state. ${ }^{47}$

Another of the critiques levelled against the Anzac legend in recent times is its obvert masculinity. Although calls for a national nurses' memorial in various locations date back to the mid-1940s_-before the Anzac Parade project was even conceived-the placement of a memorial to women in the heart of the masculine war epic speaks to a change in how Australia perceived the role of women in war, and in society

44 Craig Stockings, 'There is an Idea that the Australian is a Born Soldier', in Craig Stockings (ed.), Zombie Myths of Australian History: 10 Myths That Will Not Die (Sydney: UNSW Press, 2010), pp. 93-4.

45 Reynolds and Lake, What's Wrong with Anzac?, p. 158.

46 In what is perhaps the best reasoned critique of the new scholarship on Anzac, Mervyn Bendle characterises 'an intellectual jihad against the historical narratives through which the Australian people seek to understand their nation's history, sustain a sense of national identity and redeem the promise of generations past'. Mervyn Bendle, 'The military historians' war on the Anzac legend', in Quadrant, Vol. 58, No. 4 (2014), pp. 7-13.

47 David Morrison, ANZAC Day Dawn Service Address 25 April 2015 [transcript], www.awm.gov.au/talksspeeches/dawn-service-address-25-april-2015 (accessed 4 November 2015). 
more generally. ${ }^{48}$ Certainly, the role of women in war has largely been omitted from the official histories of the wars. A focus on gallantry and violence has tended to relegate women to supporting actors. ${ }^{49}$ This tacit misogyny carried into the choice of memorials on Anzac Parade. The decision in 1999 to dedicate a memorial to the nurses who had died during Australia's wars was, in a way, an acceptance that women had contributed and sacrificed in defence of the values the Parade celebrates.

Only two niches remain to be filled on Anzac Parade. Glossy 'coming soon' signs speak of a memorial to commemorate the Boer War and another for Australia's peacekeeping missions. It will be interesting to see how these two new memorials fit within the traditions already established on Anzac Parade, as well as more modern interpretations of Australian military history. The Boer War Memorial in particular must balance the nostalgic reverence of 'Australia's first war' and the mythology of Breaker Morant with the moral ambiguity of an asymmetric colonial conflict fought over imperial values far removed from those of modern Australians. ${ }^{50}$ Peacekeeping carries far nobler connotations, especially the deployments to East Timor and the Solomon Islands, where Australia was able to mobilise its military power as a 'good international citizen' to protect the persecuted. ${ }^{51}$ Here again, however, we risk producing myths that may not fit with the historical evidence. ${ }^{52}$

With the filling of the last two niches on Anzac Parade, the question then becomes how we represent our present generation's wars and those that are still to be fought. The invasion of Iraq in 2003 was more divisive than any conflict since Vietnam; while the Afghan war dragged on so long that community interest had all but waned by the end. In his 2014 book, Anzac's Long Shadow: The Cost of our National Obsession, Afghanistan veteran and historian James Brown argues that the Anzac legend is so removed from the modern military experience that it clouds the true narratives of what he and others experienced..$^{33}$

In 2011, an aborted attempt to build two enormous memorials to the two World Wars at the extreme southern end of Anzac Parade precipitated a parliamentary inquiry into the Canberra memorial project. Its findings were damning about what it considered the politicised and opaque nature of memorial planning. ${ }^{54}$ Indeed, from its inception in the mind of Walter Burley Griffin, Anzac Parade has been a plaything of shifting purpose and expectation. Beginning as a park and then

48 Canberra Times, 'Nurses' Memorial for Canberra', 26 November 1945; Inglis, Sacred Places, pp. 486-7.

49 Caroline Jones, 'Unfortunate omission: Writing women out of the Anzac legend', in Bulletin (Bibliographical Society of Australia and New Zealand) Vol. 28, No. 1-2, (2004), p. 111.

50 Denis Judd and Keith Surridge, The Boer War: A History (London: I.B. Tauris, 2013), pp. 221-2.

51 Derek McDougall, 'Australia's Peacekeeping Role in the Post-Cold War Era', in Contemporary Southeast Asia, Vol. 24, No. 3 (2002), pp. 593-4.

52 Clinton Fernandes, 'Two Tales of Timor', in Craig Stockings (ed.), Zombie Myths of Australian History: 10 Myths That Will Not Die (Sydney: UNSW Press, 2010), p. 213.

53 James Brown, Anzac's Long Shadow: The Cost of our National Obsession, (Melbourne: Redback, 2014), p. 77.

54 Ross Peake, 'Memorial Process Flawed', Canberra Times, 23 November 2011. 
a freeway, it was redesigned to service Bean's new martial creation story: a grand statement on the cult of the Anzac and the virtues it represented. Yet, slowly, this narrative shifted, first in in its acceptance of multicultural Australia through the Hellenic Memorial, and later through the redefinition of the Anzac story to include the Vietnam veteran and the nurse. The ad hoc development of Anzac Parade has undeniably led to an aesthetic and historical disjuncture. It prompts the question: what is it about war that we wish to remember? Because ultimately memorials are, for those who build them, the manifestation of the memories they desire someone else to remember. The Anzac legend may change with time, but each memorial on Anzac Parade is a moment fixed in time, the embodiment of a set of values destined to fade into memory: much like the Anzacs they were built to honour.

\section{Bibliography}

\section{Primary sources}

Newspaper articles and letters to the editor

Blewett, Dennis, 'Airman's Tribute to the Fallen Takes Shape', The Courier, 26 August 1971.

Canberra News, 'Monstrosity Stays', 3 May 1971.

Canberra Times, 'Nurses' Memorial for Canberra', 26 November 1945.

Grishin, Sasha, 'Street Art Finds Favour', Canberra Times, 9 May 1986.

Lindh, A., letter to the editor, Canberra Times, 2 April 1973.

Peake, Ross, 'Memorial Process Flawed', Canberra Times, 23 November 2011.

Radclyffe, L.E., letter to the editor, Canberra Times, 2 April 1973.

Sydney Morning Herald, 'R.S.L. May Provide a Replica for Park', 31 December 1962.

Government documents and letters

Anthony, Doug letter to Robert Menzies, 5 May 1965, National Archives of Australia: A463, 1964/2781 PART 1.

Canberra National Monuments Committee, A Proposal for a Memorial to the Rats of Tobruk (report to the committee, 1981) National Archives of Australia: A1209, 1982/690 PART 2. 
Department of Foreign Affairs and Trade, Cable to the Australian Embassy in Turkey 29th May 1986, National Archives of Australia: A463, 1986/996, p. 30-1.

Ellicott, Bob letter to Malcom Fraser, 4 August 1980, National Archives of Australia: A1209, 1982/690 PART 1 p. 73.

Griffith, A.T. letter to E.J. Bunting, 11 March 1963, National Archives of Australia: A463, 1964/2781 PART 1.

Holford, William, quoted in National Capital Authority ANZAC Parade Urban Design: Commissioned Competition (National Capital Authority Library: C21 NAT 'B' 17867, 1992).

National Capital Development Commission, National Memorial to the Australian Navy: Conditions for a Two Stage Design Competition (1963), National Archives of Australia: A1209, 1982/690 PART 3.

National Capital Development Commission, The Place of Monuments in the National Capital (Report to the National Memorials Committee, 1961), National Archives of Australia A463, 1964/875.

National Capital Planning Authority, ANZAC Parade Design Studies (Report prepared by Lester Associates, 1991), National Capital Authority Library.

Sodersten, Emil, National War Memorial Canberra, Site Development and Approaches (Report to the War Memorial Board, 21/5/1936), quoted in National Capital Authority, ANZAC Parade Urban Design: Commissioned Competition (National Capital Authority Library: C21 NAT 'B' 17867, 1992).

\section{Transcripts of speeches}

Hawke, Bob, Launching of the National Appeal for the Australian-Hellenic Memorial Canberra, 1 April 1987 [Press transcript], National Archives of Australia: A463, 1986/996.

Hughes, Billy, Speech given on the opening of the Desert Mounted Corps memorial, Port Said, Egypt, 1932. Quoted in Australian War Memorial, Desert Mounted Corps Memorial (Report to memorial board), Australian War Memorial: AWM27, 623/18.

Marshal, J.R., Speech given at the opening of the Desert Mounted Corps Memorial, Canberra, 19th April 1968, Quoted in Australian War Memorial, Desert Mounted Corps Memorial-Unveiling of replica in ANZAC Parade, Canberra, 19 April 1968 (Report to the board, 1968) Australian War Memorial: AWM27, 623/18. 
Morrison, David, Anzac Day Dawn Service Address, 25 April 2015 [Transcript], www.awm.gov.au/talks-speeches/dawn-service-address-25-april-2015 (accessed 4 November 2015).

\section{Secondary sources}

Anderson, Zoe. (2013). 'Reading "Multiculturalism": A Historiography of Policy and Ideal in Australia', in History Compass 11(11), 905-17. doi.org/10.1111/ hic3.12098

Bendle, Mervyn. (2014). 'The Military Historians' War on the Anzac Legend', Quadrant 58(4), 7-13.

Brown, James. (2014). Anzac's Long Shadow: The Cost of our National Obsession Melbourne: Redback.

Crotty, Martin. (2007). 'The Anzac Citizen: Towards a History of the RSL', Australian Journal of Politics and History 53(2). doi.org/10.1111/j.1467-8497.2007.00453.x

Crowe, Ambrose. (1999). The Battle After the War: The Story of Australia's Vietnam Veterans. Sydney: Allen \& Unwin.

Dennis, Peter, Grey, Jeffrey, Morris, Ewan, Prior, Robin and Bou, Jean (eds). (2008). The Oxford Companion to Australian Military History (2nd edition). Oxford: Oxford University Press.

Doyle, Jeff. (2000). 'Another Forgotten War Remembered: The Australian National Korean War Memorial, ANZAC Parade, Canberra'. In Peter Dennis and Jeffery Grey (eds), The Korean War 1950-1953: A 50 Year Retrospective. Canberra: Army History Unit.

Fernandes, Clinton. (2010). 'Two Tales of Timor'. In Craig Stockings (ed.), Zombie Myths of Australian History: 10 Myths That Will Not Die. Sydney: UNSW Press.

Grey, Jeffery. (1991). 'Vietnam, Anzac and the Veteran'. In Peter Pierce, Jeff Doyle \& Jeffrey Grey (eds), Vietnam Days: Australia and the Impact of Vietnam. Melbourne: Penguin Australia.

Inglis, Ken. (1969). C.E.W. Bean: Australian Historian. Brisbane: University of Queensland Press.

Inglis, Ken. (2008). Sacred Places: War Memorials in the Australian Landscape. Melbourne: Melbourne University Press.

Jones, Caroline. (2004). 'Unfortunate Omission: Writing Women out of the Anzac Legend', Bulletin (Bibliographical Society of Australia and New Zealand) 28(12), 111-21. 
Judd, Denis and Surridge, Keith. (2013). The Boer War: A History. London: I.B. Tauris.

Marling, Karal Ann and Silberman, Robert. (1987). 'The Statue near the Wall: The Vietnam Veterans Memorial and the Art of Remembering', Smithson Studies in American Art 1(1), 4-28. doi.org/10.1086/smitstudamerart.1.1.3108969

McDougall, Derek. (2002). 'Australia's Peacekeeping Role in the Post-Cold War Era', in Contemporary Southeast Asia 24(3), 590-608 . doi.org/10.1355/CS24$3 \mathrm{H}$

Pedersen, Peter. (2007). 'The AIF-As Good as the ANZAC Legend Says?', The Sydney Papers 3, 168-77.

Pegrum, Rodger. (1983). The Bush Capital: How Australia Chose Canberra as Its Federal Capital. Sydney: Hale and Iremonger.

Reynolds, Henry and Lake, Marilyn. (2011). 'Epilogue: Moving On?'. In Marilyn Lake and Henry Reynolds (eds), What's Wrong with ANZAC? The Militarisation of Australian History. Sydney: UNSW Press. doi.org/10.1017/ cbo9780511762017.016

Scott, Ernest. (1948). Official History of Australia in the War of 1914-1918, Vol. 11. Sydney: Angus and Robertson. www.awm.gov.au/collection/RCDIG1069950/ (accessed 2 October 2015).

Scruggs, Jan and Swerdlow, Joel. (1985). To Heal a Nation: The Vietnam Veterans Memorial. New York: Harper Rowe.

Stockings, Craig. (2010). 'There is an Idea that the Australian is a Born Soldier'. In Craig Stockings (ed.), Zombie Myths of Australian History: 10 Myths That Will Not Die. Sydney: UNSW Press.

Taylor, Ken. (1996). 'ANZAC Parade: A Landscape of Memory', Canberra Historical Journal 36, 2-12.

Thomson, Alistair. (1994). ANZAC Memories: Living with the Legend. Melbourne: Oxford University Press. 
This text is taken from The ANU Undergraduate Research Journal, Volume Eight, 2016, edited by Daniel McKay, published 2017 by ANU eView, The Australian National University, Canberra, Australia.

dx.doi.org/10.22459/AURJ.08.2016.10 